\title{
Tongue and Scalp Necrosis: Simultaneous Initial Complications Revealing Giant Cell Arteritis
}

CHRISTELLE FONGAUFIER, MD, Department of Stomatology, Maxillofacial and Plastic Surgery, University Hospital, and UFR Medicine, University of Strasbourg; AURÉLIEN GUFFROY, MD, Department of Clinical Immunology and Internal Medicine, National Reference Center for Rare Autoimmune Diseases, Strasbourg University Hospital, and UFR Medicine, University of Strasbourg; JEAN-CHRISTOPHE LUTZ, MD, PhD, Department of Stomatology, Maxillofacial and Plastic Surgery, University Hospital, and UFR Medicine, University of Strasbourg, Strasbourg, France. Address correspondence to Dr. C. Fongaufier, Department of Stomatology, Maxillofacial and Plastic Surgery, Strasbourg University, Hospital, Hospices Civils, 1 Place de l'Hôpital, 67091 Strasbourg Cedex, Strasbourg, France. E-mail: christelle.fongaufier@chru-strasbourg.fr. An approval statement from the ethical committee of the Faculties of Medicine and Dentistry of Strasbourg has been obtained (approval no. 2017-75) and written consent was obtained. J Rheumatol 2018;45:873-4; doi:10.3899/jrheum.171321

Giant cell arteritis (GCA), one of the first causes of arteritis in the elderly, affects the vascular territory of the external carotid artery, especially in its superficial temporal branch ${ }^{1}$.

A 66-year-old patient was referred for a fever and rapidly progressive deterioration of his general state. The first

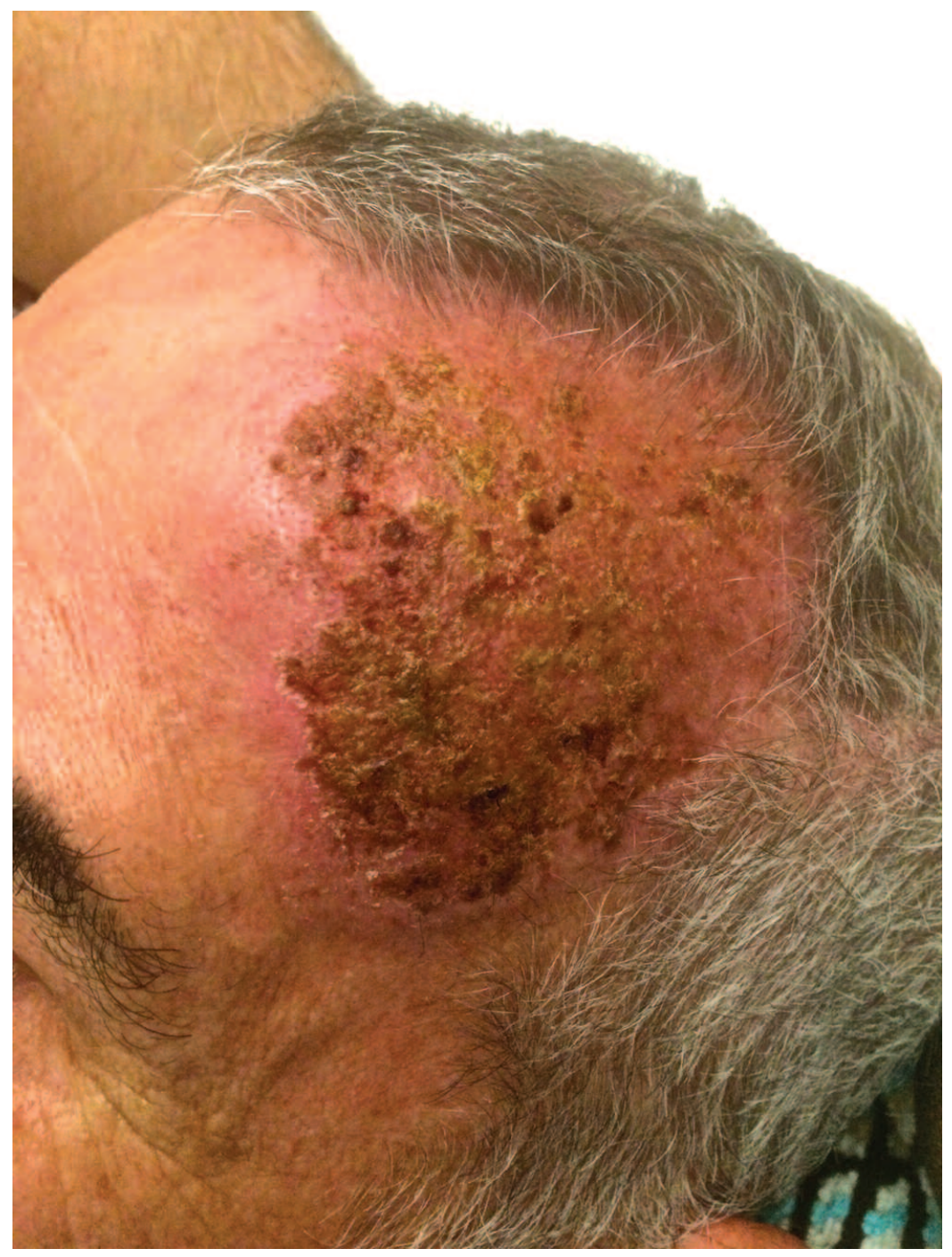

symptoms appeared several days before, while the patient was visiting Thailand: fever and unusual bilateral headaches were followed by glossodynia and jaw claudication. Within about $2 \mathrm{~h}$, tongue edema and jaw pain appeared. Intermittent binocular diplopia with transient amaurosis was also noted.
Figure 1. Ischemic lesions in the left temporal scalp featuring areas of necrosis at Day 6. Such lesions are secondary to arteritis of the superficial temporal artery.

Personal non-commercial use only. The Journal of Rheumatology Copyright @ 2018. All rights reserved. 


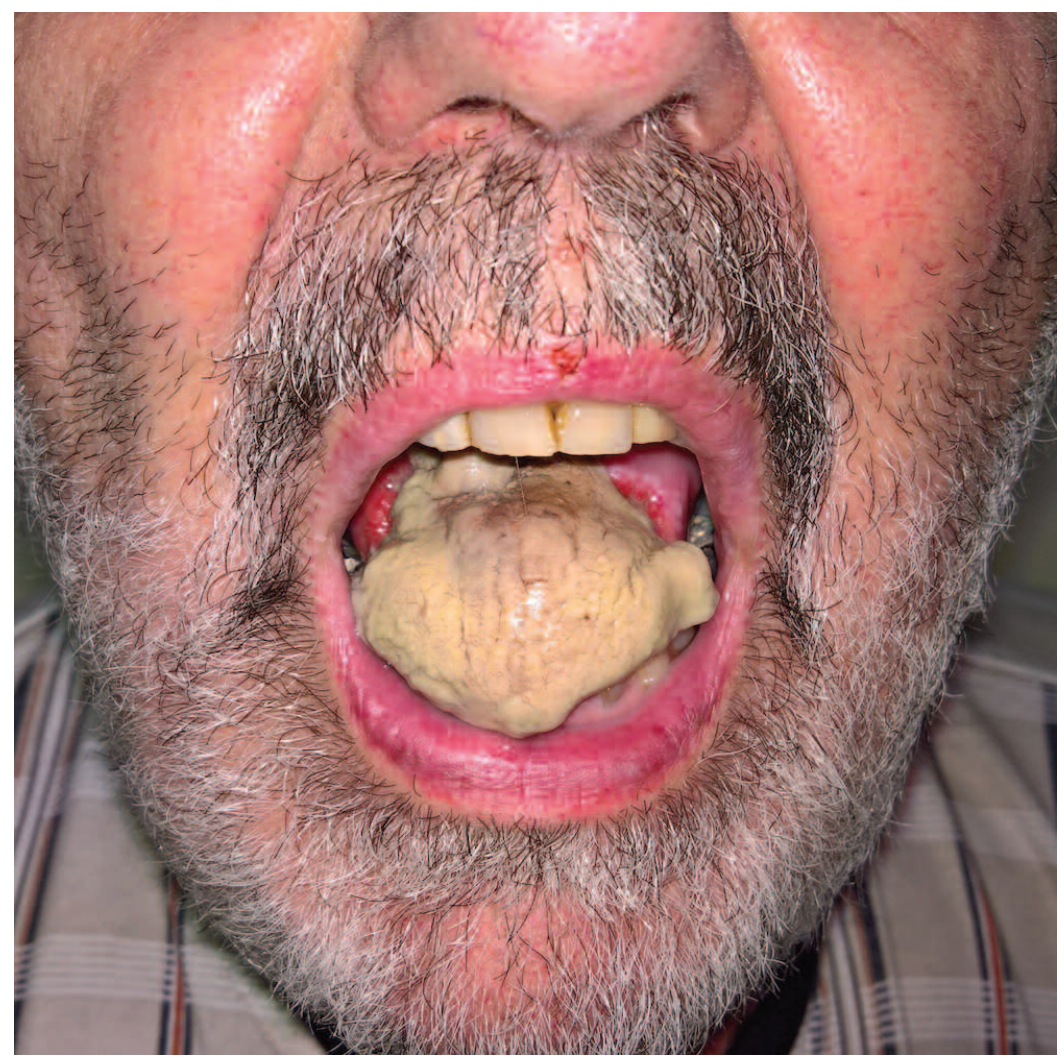

Figure 2. Necrosis of the anterior two-thirds of the tongue body at Day 14. Such lesions are secondary to arteritis of the lingual artery.

An erythematous and scabbed rash then developed on the patient's scalp, featuring a necrosis area (Figure 1, and Supplementary Figures 1 and 2, available with the online version of this article). The tongue evolved toward cyanosis, further to necrosis (Figure 2, and Supplementary Figures 3-5, available with the online version of this article). The patient's case history included bilateral shoulder arthralgia. C-reactive protein was $120 \mathrm{mg} / \mathrm{l}$, and temporal artery biopsy confirmed the diagnosis of GCA. Treatment consisted of high-dose intravenous corticosteroids (methylprednisolone, $1.5 \mathrm{mg} / \mathrm{kg} / \mathrm{d}$ for $3 \mathrm{~d})^{2,3}$. Articular pain, headaches, and ophthalmologic symptoms drastically improved in $<48 \mathrm{~h}$, while the scalp lesions responded at a slower rate. Emergency surgery for resection of the tongue necrotic tissue was performed. Because there was satisfactory primary healing, no further treatment was required.

The rich arterial supply network provided by the lingual artery usually prevents acute necrosis of the tongue body. However, even if they are rare, scalp ${ }^{4}$ and tongue ${ }^{5}$ necrosis are likely to simultaneously occur, as in our patient.
Better awareness of GCA initial signs and close collaboration among specialists could have allowed early diagnosis, thereby preventing such severe complications.

\section{ONLINE SUPPLEMENT}

Supplementary material accompanies the online version of this article.

\section{REFERENCES}

1. Jennette JC. Overview of the 2012 revised International Chapel Hill Consensus Conference nomenclature of vasculitides. Clin Exp Nephrol 2013;17:603-6.

2. Hoffman GS. Giant cell arteritis. Ann Intern Med 2016;165: ITC65-80.

3. Weyand CM, Goronzy JJ. Giant-cell arteritis and polymyalgia rheumatica. Ann Intern Med 2003;139:505-15.

4. Akram Q, Chinoy H. Scalp necrosis associated with giant-cell arteritis. N Engl J Med 2016;374:e6.

5. Grant SW, Underhill HC, Atkin P. Giant cell arteritis affecting the tongue: a case report and review of the literature. Dent Update 2013;40:669-70, 673-4, 677. 